Research Paper

\title{
Propofol-Induced Protection of SH-SY5Y Cells against Hydrogen Peroxide Is Associated with the $\mathrm{HO}-\mathrm{I}$ via the ERK Pathway
}

\author{
Jing Gu, Meng Chi, Xuechao Sun, Guonian Wang ${ }^{\bowtie}$, Mingming Li, Li Liu and Xuan Li \\ Department of Anesthesiology, Third Affiliated Hospital of Harbin Medical University, No. 6 Baojian Rd., Nangang District, Harbin 150081, \\ China. \\ $\triangle$ Corresponding author: Dr. Guonian Wang, Department of Anesthesiology, Third Affiliated Hospital of Harbin Medical University, No. 6 \\ Baojian Rd., Nangang District, Harbin 150081, China. wangguonian609cn@yahoo.com.cn; Tel.: +86-0451-86298332.
}

() Ivyspring International Publisher. This is an open-access article distributed under the terms of the Creative Commons License (http://creativecommons.org/ licenses/by-nc-nd/3.0/). Reproduction is permitted for personal, noncommercial use, provided that the article is in whole, unmodified, and properly cited.

Received: 2012.09.03; Accepted: 2013.03.07; Published: 2013.03.19

\begin{abstract}
Propofol (2, 6-diisopropylphenol), is an anesthetic and routinely used for the humans sedation during surgery. The potent inducers of phase II detoxifying and antioxidant stress responsive to propofol were investigated. First, a dose of $25-100 \mu M$ propofol showed no significant cytotoxicity on SH-SY5Y cells and pre-treatment of SH-SY5Y cells with propofol $(25-100 \mu \mathrm{M})$ for $8 \mathrm{~h}$ prevented cell death and maintained cell integrity following exposure to I mM hydrogen peroxide by MTT assays. Then, an increase in the generation of ROS following hydrogen peroxide treatment was significantly attenuated by $8 \mathrm{~h}$ pre-treatment with propofol. Additionally, the potential roles of ERK, $P 38$ MAPK and JNK in the regulation of propofol-induced endogenous HO-I expression in $\mathrm{SH}-\mathrm{SY} 5 \mathrm{Y}$ cells were estimated by Western blotting assays. Results showed that propofol significantly increased the phosphorylation levels of ERK, p 38 MAPK and JNK and antioxidant stress responsive to propofol was attenuated by the inhibition of ERK signaling biochemical inhibitors. These results suggest that the ERK pathway plays an important role in the regulation of propofol-mediated antioxidant effects in SH-SY5Y cells.
\end{abstract}

Key words: Propofol; ERK; p 38 MAPK; JNK; SH-SY5Y cells.

\section{Introduction}

It is generally accepted that oxidative stress could induce cell damage and lead to a variety of neurodegenerative disorders such as Parkinson's and Alzheimer's diseases [1-3]. Hydrogen peroxide $\left(\mathrm{H}_{2} \mathrm{O}_{2}\right)$ is one of the reactive oxygen species which could lead to lipid peroxidation and DNA damage $[4,5] . \mathrm{H}_{2} \mathrm{O}_{2}$ could induce the production of reactive oxygen species (ROS) in the brain. Recent studies have demonstrated that high levels of ROS induce nervous system cell death [8-10]. Mammalian cells have developed several protective mechanisms involving both antioxidants and protective enzymes to defend ROS damage $[11,12]$. HO-1 is one of antioxidant enzymes with potent anti-inflammatory, anti-oxidant and an- ti-proliferative effects [13-15]. HO-1 is known as a heat shock protein induced by the oxidative stress. In clinical practice, increased HO-1 expression prolongs cardiac xenograft survival, facilitates cold preservation of liver transplants and reduces the severity of ischemia reperfusion injury in kidney transplants [16-18]. In addition, overexpression of HO-1 also has effective neuroprotection against cold-induced secondary brain injury [19]. The expression of HO-1 could be induced by a range of substances, such as $\mathrm{H}_{2} \mathrm{O}_{2}$, phlorotannin compound, heavy metals, endotoxin, organic chemicals and so on [20-22]. Acquaviva et al. [23] showed that propofol induces expression of HO-1 in astrocytes under normal conditions. Expres- 
sion of HO-1 has related to the several signal transduction pathways, such as mitogen-activated protein kinases (MAPKs) including extracellular signal-regulated kinases (ERKs), cJun-N-terminal kinases (JNKs) and p38-MAPK, depending on cell species and treatment conditions [24-27]. The expression also requires the activation of several signal transduction pathways such as protein kinase C (PKC) and phosphatidylinositol 3-kinase (PI3K) [28].

Propofol (2, 6-diisopropylphenol, Fig 1) was always described as an anesthetic [29]. Propofol produces a variety of pharmacodynamic effects, such as hypnosis to general anesthesia; relax amnestic and muscle; decrease the production of pro-inflammatory cytokines and alters the biosynthesis of nitric oxide (NO) [30,31]. Additionally, propofol also could inhibit chemotaxis, attachment, migration, phagocytosis, the production of ROS and so on [32]. The protective effects of propofol were attributed to its capability of scavenging $\mathrm{H}_{2} \mathrm{O}_{2}$, reducing the formation of lipid peroxides, decreasing the expression levels of nitric oxide syntheses, and stabilizing the mitochondrial membrane $[33,34]$.

In the present study, we investigated a mechanism by the protection of propofol for SH-SY5Y cells from $\mathrm{H}_{2} \mathrm{O}_{2}$ induced oxidative damage. Furthermore, the possible signaling way was examined to understand the mechanisms. We also investigated the effect of propofol on expression of HO-1 in SH-SY5Y cells under oxidative stress conditions.

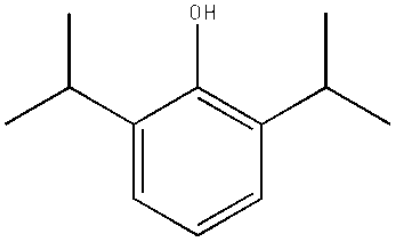

Figure I. Structure of propofol.

\section{Results and Discussion}

\section{I. Propofol inhibits $\mathrm{H}_{2} \mathrm{O}_{2}$-induced SH-SY5Y cell death}

First, the cytotoxicity effects propofol on SH-SY5Y cells after $24 \mathrm{~h}$ exposure were examined (Figure 2a). The relative cell survival rate of SH-SY5Y cells treated with $0-100 \mu \mathrm{M}$ propofol was over $80 \%$, as analyzed by the MTT assay. Then, the effect of propofol on $\mathrm{H}_{2} \mathrm{O}_{2}$-induced cell death was determined. SH-SY5Y cells were treated with propofol (25-100 $\mu \mathrm{M}$ ) or vehicle for $8 \mathrm{~h}$, after that, the cells was exposed to $1 \mathrm{mM} \mathrm{H}_{2} \mathrm{O}_{2}$ or vehicle in fresh medium for $24 \mathrm{~h}$. As shown in Fig. 2b, the survival rates of SH-SY5Y cells treated with $25 \mu \mathrm{M}, 50 \mu \mathrm{M}, 75 \mu \mathrm{M}$ and $100 \mu \mathrm{M}$ propofol were $60.94 \%, 72.19 \%, 80.43 \%$ and $87.3 \%$ respectively. The results indicate that a dose of $0-100$ $\mu \mathrm{M}$ propofol does not contribute significantly to cytotoxicity in SH-SY5Y cells, and affords cytoprotection to the cell cultures in a concentration-dependent manner. Taken together, these data show that propofol inhibits $\mathrm{H}_{2} \mathrm{O}_{2}$-induced apoptosis in SH-SY5Y cells.
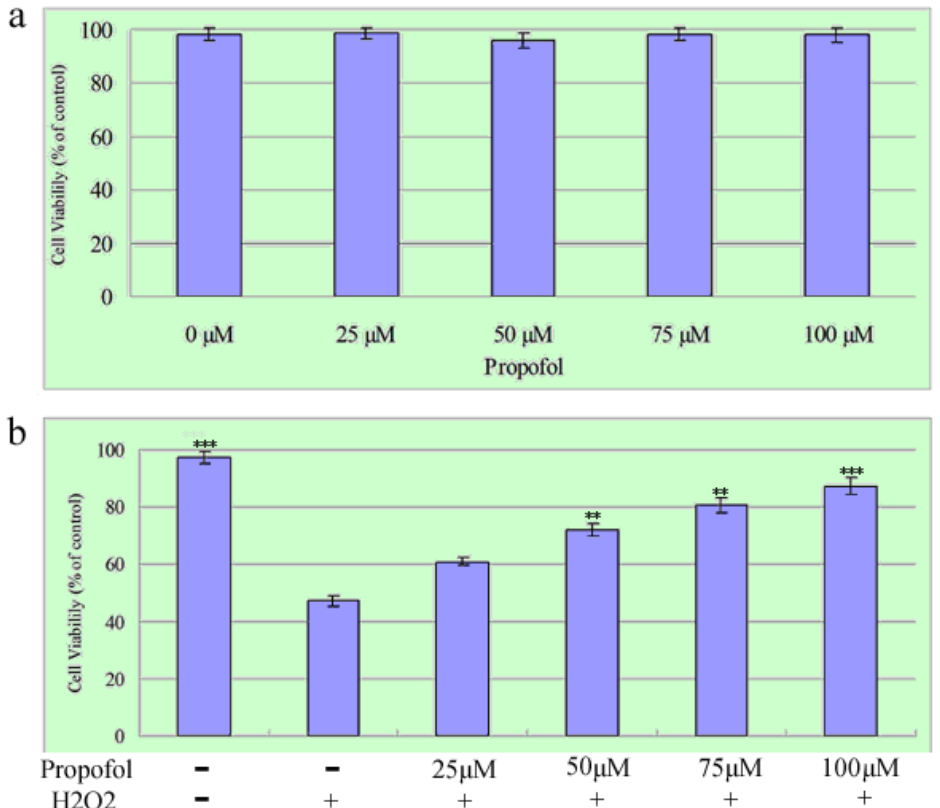

Figure 2. Propofol prevents $\mathrm{H}_{2} \mathrm{O}_{2}$-induced cell death; the results (presented as mean \pm S.D.) are from three independent tests. (a) Cells were exposed to various concentrations of propofol for $24 \mathrm{~h}$ before being subjected to the MTT assay; (b) SH-SY5Y cells were treated with propofol $(0-100 \mu M)$ for $8 \mathrm{~h}$ then incubated with $\mathrm{H}_{2} \mathrm{O}_{2}(\mathrm{I} \mathrm{mM})$ for a further $24 \mathrm{~h}$, Cell viability was measured by MTT assays. ** and *** significant differences $\left(\mathrm{P}<0.0 \mathrm{I}\right.$ and $\mathrm{P}<0.00 \mathrm{I}$ respectively) compared with I $\mathrm{mM} \mathrm{H}_{2} \mathrm{O}_{2}$ group (the second bar). 


\subsection{Propofol Reduces $\mathrm{H}_{2} \mathrm{O}_{2}$-induced ROS Production of SH-SY5Y cell}

To determine whether propofol reduced $\mathrm{H}_{2} \mathrm{O}_{2}$-induced ROS generation in SH-SY5Y cells, cells were treated with propofol $(0-100 \mu \mathrm{M})$ for $8 \mathrm{~h}$ and then incubated with $1 \mathrm{mM} \mathrm{H}_{2} \mathrm{O}_{2}$ or vehicle for $24 \mathrm{~h}$.
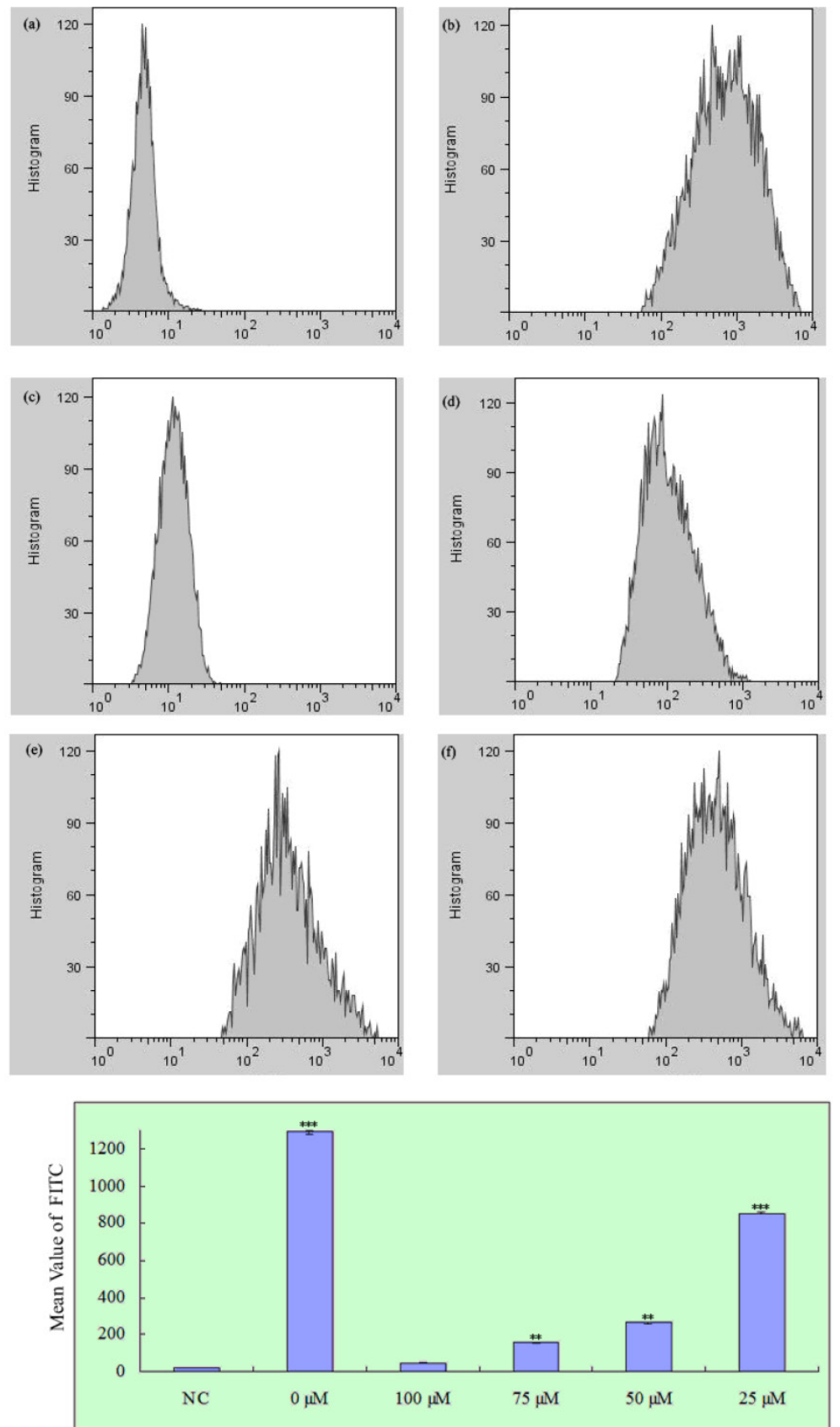

Figure 3. Effect of propofol on intracellular ROS formation in SH-SY5Y cells, fluorescence was detected by flow cytometry with FLI; results (presented as mean \pm S.D.) are from three independent tests. $* *$ and $* * *$ significant differences $(P<0.0 \mathrm{I}$ and $\mathrm{P}<0.00 \mathrm{I}$ respectively) compared with NC group. (a) Negative control; (b)-(f) Treatment with 0, 100, 75, 50 and $25 \mu \mathrm{M}$ propofol respectively. 


\subsection{ERK Signaling Pathways Participate in the propofol-Induced HO-I Expression}

To analyze the signaling pathway that could participate in the neuroprotective mechanism of propofol, the effect of propofol on extracellular signal-regulated kinase 1/2 (ERK1/2), c-Jun N-terminal kinase (JNK) and p 38 mitogen-activated protein kinase (p 38 MAPK) activation in SH-SY5Y cells was investigated. Propofol stimulated concentration increases in ERK, JNK and $\mathrm{p} 38$ MAPK phosphorylation in $\mathrm{H}_{2} \mathrm{O}_{2}$ induced SH-SY5Y cells (Fig 4). Moreover, PD98059 (an inhibitor of the ERK), SB203580 (an inhibitor of p 38 MAP kinase), and SP600125 (an inhibitor of JNK) were used in pretreatment of SH-SY5Y cells for $30 \mathrm{~min}$, and then cells were co-treated with $100 \mu \mathrm{M}$ propofol for another $8 \mathrm{~h}$, cells were incubated for $24 \mathrm{~h}$ in the presence of $\mathrm{H}_{2} \mathrm{O}_{2}$ and cell lysates were resolved in SDS-PAGE and analyzed by immunoblot with anti-HO-1 antibody (Fig 5). Propofol increased the expression of HO-1, compared with control cells. Co-incubation of the cells with propofol, $\mathrm{H}_{2} \mathrm{O}_{2}$ and the ERK inhibitor PD98059 reduced the overexpression of HO-1, indicating that ERK was implicated in the overexpression of HO-1, induced by propofol. Moreover, JNK inhibitor and p 38 MAPK inhibitor did not block the overexpression of HO-1(Fig. 4-b). These results indicate that ERK is participating in the overexpression of HO-1 afforded by propofol.

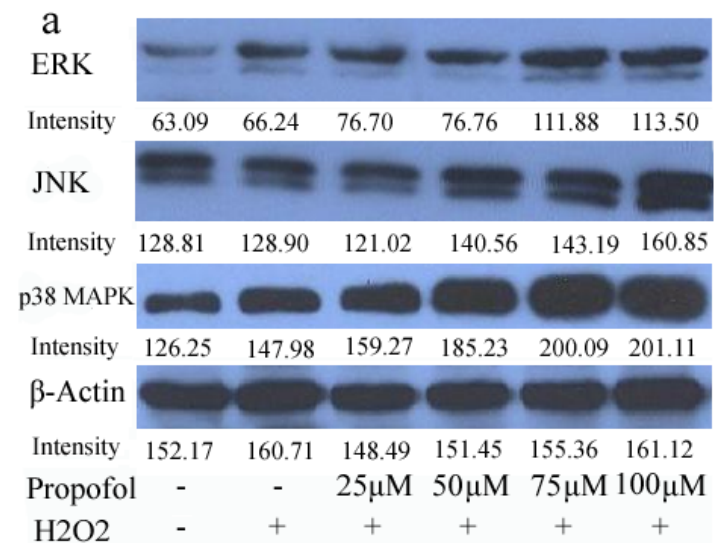

\subsection{ERK Signaling Pathways Participate in the propofol Reduces $\mathrm{H}_{2} \mathrm{O}_{2}$-induced $\mathrm{SH}-\mathrm{SY} 5 Y$ cell death and ROS Production}

To confirm the role of ERK Signaling Pathways during oxidant-mediated apoptosis, we used $\mathrm{H}_{2} \mathrm{O}_{2}$ as the apoptosis inducer. According to our experiments described before, PD98059 (an inhibitor of the ERK) or vehicle were used in pretreatment of SH-SY5Y cells for $30 \mathrm{~min}$, and then cells were co-treated with $100 \mu \mathrm{M}$ propofol for another $8 \mathrm{~h}$, after that, the cells was exposed to $1 \mathrm{mM} \mathrm{H}_{2} \mathrm{O}_{2}$ or vehicle in fresh medium for 24 $\mathrm{h}$ as analyzed by an MTT assay. For ROS production assay, PD98059 or vehicle were used in pretreatment of SH-SY5Y cells for $30 \mathrm{~min}$, then cells were treated with $100 \mu \mathrm{M}$ propofol or vehicle for $8 \mathrm{~h}$ and treated 1 $\mathrm{mM} \mathrm{H} \mathrm{H}_{2}$ or vehicle for $24 \mathrm{~h}$. Flowed that cells was treated with $\mathrm{H}_{2}$-DCFDA for $20 \mathrm{~min}$, samples were analyzed by BD Flow cytometry with channel FL1, and the data were shown in Fig.5. From Fig.5, treatment with propofol significantly reduced the $\mathrm{H}_{2} \mathrm{O}_{2}$-induced SH-SY5Y cell death and ROS generation, but co-incubation of the cells with propofol, $\mathrm{H}_{2} \mathrm{O}_{2}$ and the ERK inhibitor PD98059 increase the SH-SY5Y cell death and ROS Production, indicating that the ERK inhibitor attenuates the effect of propofol in SH-SY5Y cell.

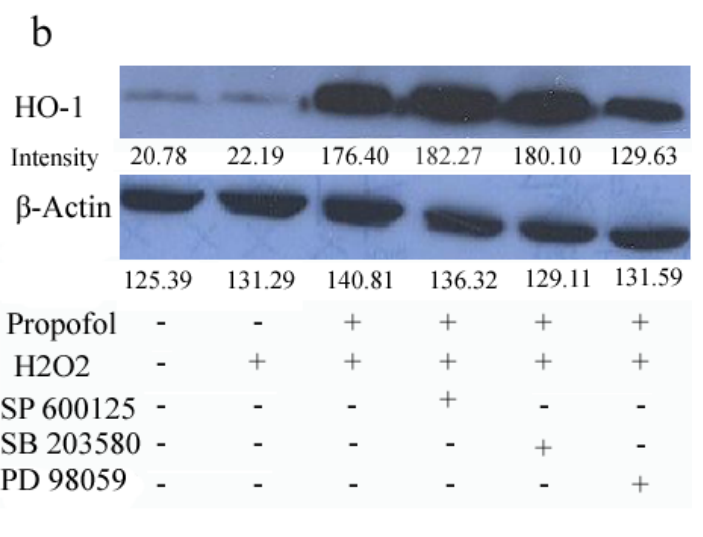

Figure 4. ERK signaling pathway participates in the propofol-induced HO-I expression; results (presented as mean \pm S.D.) are from three independent tests. (a) Cells were treated with propofol of different concentrations. Total cell extracts were prepared and subjected to western-blot analysis in order to detect the active phosphorylated forms of p 38 MAPK, ERKI/2 and JNK; (b) Cells were treated with 10 $\mu \mathrm{M}$ SB203580, SP600 I25, or PD98059 for $30 \mathrm{~min}$ and challenged with $100 \mu \mathrm{M}$ propofol for another $8 \mathrm{~h}$ then incubated with $\mathrm{H}_{2} \mathrm{O}_{2}$ for 24 h. Total cell extracts were prepared and subjected to western blot analysis for detection of the levels of $\mathrm{HO}-\mathrm{I}$. 

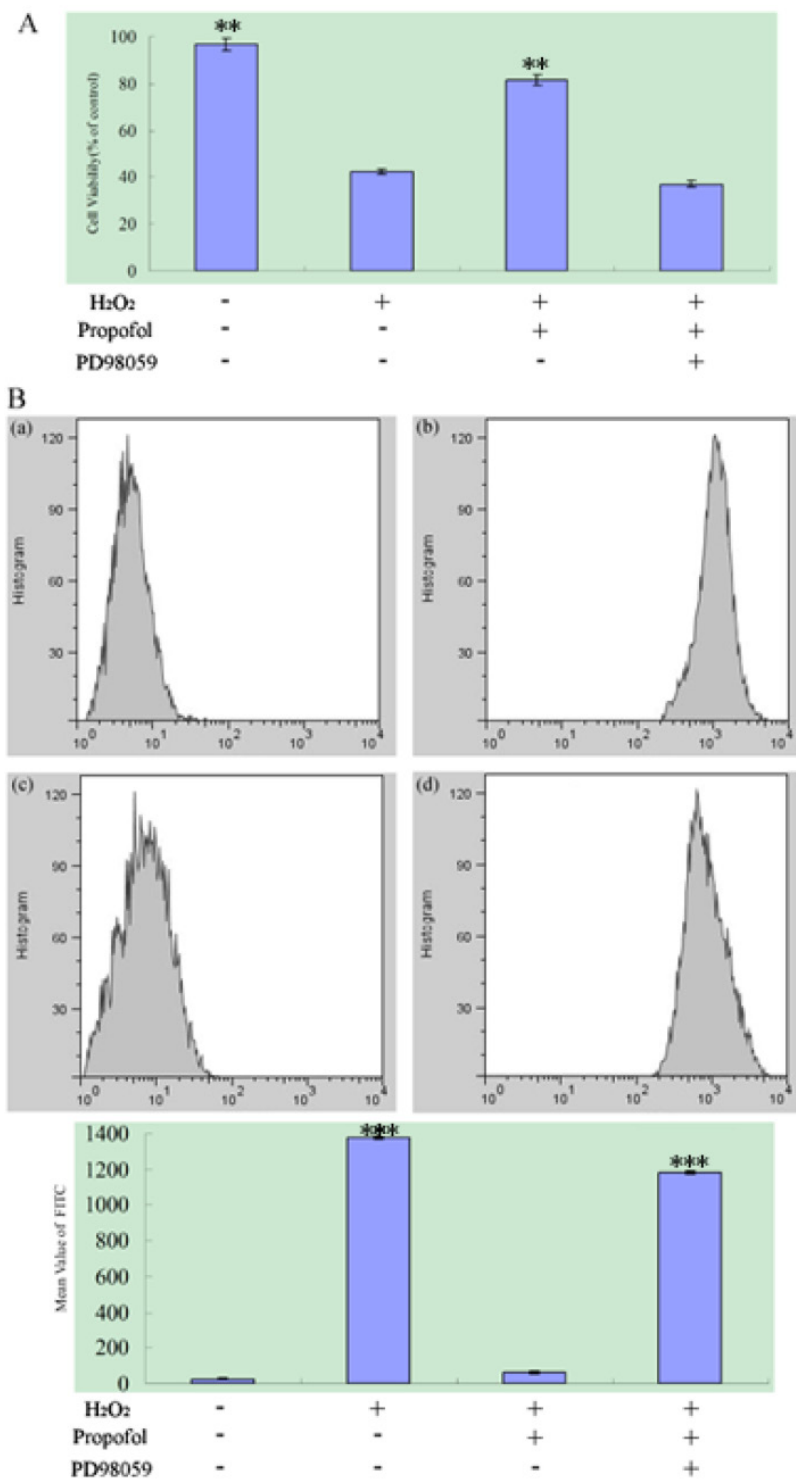

Figure 5. ERK signaling pathway participate in the propofol reduces $\mathrm{H}_{2} \mathrm{O}_{2}$-induced $\mathrm{SH}-\mathrm{SY} 5 \mathrm{Y}$ cell death and ROS Production; results (presented as mean \pm S.D.) are from three independent tests. (A) ERK signaling pathway participate in the propofol reduces $\mathrm{H}_{2} \mathrm{O}_{2}$-induced cell death. ** significant differences $(\mathrm{P}<0.0 \mathrm{I})$ compared with I $\mathrm{mM} \mathrm{H}_{2} \mathrm{O}_{2}$ group (the second bar). (B) The ROS production assay. (B-a) Blank control; (B-b) SH-SY5Y cell was treated with $\mathrm{H}_{2} \mathrm{O}_{2}$; (B-c) SH-SY5Y cell were treated with $\mathrm{H}_{2} \mathrm{O}_{2}$ and propofol; (B-d) The cells was treated with propofol for co-incubation, $\mathrm{H}_{2} \mathrm{O}_{2}$ and the ERK inhibitor PD98059. *** significant differences $(\mathrm{P}<0.00 \mathrm{I})$ compared with the blank control group (the first bar).

The purpose of this study was to elucidate the role of propofol in SH-SY5Y under oxidative stress. All data provide strong evidence that propofol could protect SH-SY5Y against oxidative stress via the ERK pathway and induction of the antioxidant enzyme HO-1. Propofol was able to protect neuroblastoma cells against oxidant stress as observed [35]. For example, the survival rates of SH-SY5Y cells treated with $25 \mu \mathrm{M}-100 \mu \mathrm{M}$ propofol were increase compared with cells untreated with propofol (47.11\%). This result refers that the high concentrations of propofol against $\mathrm{H}_{2} \mathrm{O}_{2}$ could be exerting a direct free radical scavenging effect. The antioxidant enzyme HO-1 was induced by propofol which related to the blocking ROS production as shown in the experiments with the fluorescent dye $\mathrm{H}_{2}$-DCFDA. Therefore propofol was able to reduce ROS production induced by $\mathrm{H}_{2} \mathrm{O}_{2}$ treatment both endogenous and exogenous [36]. HO-1 is an isoform which belongs to $\mathrm{HO}$ antioxidant enzyme induced in response to a variety of stress-inducing pathological conditions such as prolongs cardiac xenograft survival; facilitates cold preservation of liver transplants and so on. Maines [37] found that there is a low expression of HO-1 in- 
duced by $\mathrm{H}_{2} \mathrm{O}_{2}$ in neurons. Therefore, HO-1 represents a physiological protective mechanism against oxidative stress is generally accepted $[38,39]$. In this study, propofol was able to up-regulate $\mathrm{HO}-1$ and this effect was related to the protective effects of propofol.

The fact that propofol-induced protective effect was prevented by the ERK inhibitor indicates that ERK pathway is participating in the induction of antioxidant enzyme HO-1. Our results are consistent with those which were found for the propofol protected cells against ischemia/reperfusion injury in liver epithelial cells [40]. Based on our present results, propofol exerts a protective effect by modulating signaling pathways in neuronal cells under oxidative stress. Collectively, the data suggest that propofol reduced cell death and ROS production which induced by $\mathrm{H}_{2} \mathrm{O}_{2}$ via ERK pathway. Further studies are needed to delineate the detailed mechanisms of activating ERK pathway by propofol, and which protein was in cooperation with HO-1 during oxidative stress-induced neuronal to reduce cell death.

In summary, this study shows that propofol can afford protection of SH-SY5Y neuroblastoma cells under oxidative stress conditions by induction of the antioxidant enzyme HO-1 via ERK pathway. This finding may have neuroprotective properties that might be useful in the acute treatment of stroke, to prevent neuronal damage and the ensuing neurological sequelae.

\section{Experimental}

\section{I. Cell Culture}

The human neuroblastoma SH-SY5Y cells were maintained in MEM medium supplemented with $10 \%$ fetal calf serum, $100 \mathrm{U} / \mathrm{ml}$ penicillin and $100 \mathrm{U} / \mathrm{ml}$ streptomycin in a humid atmosphere of $5 \% \mathrm{CO}_{2}$ and $95 \%$ air at $37{ }^{\circ} \mathrm{C}$. SH-SY5Y cells were plated in plates $(10 \mathrm{~cm})$. Then cells were pretreated with various concentrations $(0-100 \mu \mathrm{M})$ of propofol for $8 \mathrm{~h}$, followed by exposure to $1 \mathrm{mM}$ of $\mathrm{H}_{2} \mathrm{O}_{2}$ in the presence of the same concentrations of propofol for another $24 \mathrm{~h}$. To produce oxidative stress, $\mathrm{H}_{2} \mathrm{O}_{2}$ was freshly prepared from $30 \%$ stock solution prior to each experiment. The control cells were added with the same medium without $\mathrm{H}_{2} \mathrm{O}_{2}$ and propofol.

\subsection{Chemicals and Antibodies}

Propofol was prepared from Diprivan (Zeneca Limited, Macclesfield, and Cheshire, UK). The vehicle contained glycerol, soybean oil, purified egg phosphatide/egg lecithin, sodium hydroxide, and water. 3-[4, 5-dimethyl-2-thiazolyl]-2, 5-diphenyl-2tetrazolium bromide (MTT) were purchased from
Sigma. Other drugs and reagents used in this study were as follows: PD98059 (an inhibitor of the ERK), SB203580 (an inhibitor of p 38 MAP kinase), and SP600125 (an inhibitor of JNK) [41] were obtained from Cell Signaling Technology (Beverly, MA, USA). Antibodies against HO-1 and $\beta$-actin were obtained from Santa Cruz Biotechnology (Santa Cruz, CA, USA). Mouse monoclonal beta-actin antibody was obtained from Chemicon (Temecula, CA, USA). All other reagents were from commercial suppliers and of standard biochemical quality.

\subsection{Viability Assay}

SH-SY5Y cells were plated at a density of $1 \times 10^{4}$ cells per well in 96-well plates, and the cell viability was determined using the conventional MTT reduction assay. Briefly, after $24 \mathrm{~h}$ exposure to $\mathrm{H}_{2} \mathrm{O}_{2}, 40 \mu \mathrm{l}$ of MTT (2 mg/ml in PBS) were added to each well and the cells were incubated at $37^{\circ} \mathrm{C}$ for $4 \mathrm{~h}$. The supernatants were aspirated carefully and $100 \mu \mathrm{l}$ of dimethyl sulfoxide (DMSO) were added to each well to dissolve the precipitate and the absorbance at $490 \mathrm{~nm}$ was measured with a microplate reader (BIO-RAD Model 3550, CA, USA). The cell viability ratio was calculated by the following formula: Inhibitory ratio $(\%)=\left[\left(\mathrm{OD}_{\text {control }}-\mathrm{OD}_{\text {treated }}\right) /\left(\mathrm{OD}_{\text {control }}\right)\right] \times 100 \%$.

\subsection{Flow cytometric detection of reactive oxygen species (ROS)}

ROS production in SH-SY5Y cells was measured using the redoxsensitive fluorescent dye $\mathrm{H}_{2}$ - DCFDA. After pretreatment with propofol or vehicle $8 \mathrm{~h}$, then treatment with $1 \mathrm{mM} \mathrm{H}_{2} \mathrm{O}_{2}$ for $24 \mathrm{~h}$, cells were incubated with $25 \mu \mathrm{M} \mathrm{H}_{2}$-DCFDA for $20 \mathrm{~min}$. The cells were rinsed twice with phenol-red-free DMEM containing $1 \%$ FBS, and fluorescence was detected on flow cytometry with FL1.

\subsection{Western-Blot Analysis}

For isolation of protein fractions, SH-SY5Y cells $\left(1 \times 10^{6}\right)$ were seeded in a $6 \mathrm{~cm}$ plate and incubated at $37^{\circ} \mathrm{C}$ for $24 \mathrm{~h}$. Cells were pretreated with various concentrations of propofol for $8 \mathrm{~h}$ and then washed twice with ice-cold PBS, and lysed using cell lysis buffer [20 mM Tris pH 7.5, $150 \mathrm{mM} \mathrm{NaCl}, 1 \%$ Triton $\mathrm{X}-100,2.5 \mathrm{mM}$ sodium pyrophosphate, $1 \mathrm{mM}$ EDTA, $1 \% \mathrm{Na}_{3} \mathrm{CO}_{4}, 0.5 \mathrm{~g} / \mathrm{mL}$ leupeptin, $1 \mathrm{mM}$ phenylmethanesulfonyl fluoride (PMSF)]. The lysates were collected by scraping from the plates and then centrifuged at $10,000 \mathrm{rpm}$ at $4{ }^{\circ} \mathrm{C}$ for $5 \mathrm{~min}$. The protein samples $(20 \mu \mathrm{g})$ were loaded on a $12 \%$ of SDS-polyacrylamide gel for electrophoresis, and transferred onto PVDF transfer membranes (Millipore, Billerica, MA, USA) at $0.8 \mathrm{~mA} / \mathrm{cm} 2$ for $2 \mathrm{~h}$. 
Membranes were blocked at room temperature for $2 \mathrm{~h}$ with blocking solution (1\% BSA in PBS plus $0.05 \%$ Tween-20). Membranes were incubated overnight at 4 ${ }^{\circ} \mathrm{C}$ with primary anti-bodies at a 1:1000 dilution (Biosynthesis Biotechnology Company, Beijing, China) in blocking solution. After three washings in TBST for each $5 \mathrm{~min}$, membranes were incubated for $1 \mathrm{~h}$ at room temperature with an alkaline phosphatase peroxidase-conjugated anti-mouse secondary antibody at a dilution of 1:500 in blocking solution. Detection was performed by the BCIP/NBT Alkaline Phosphatase Color Development Kit (Beyotime Institute of Biotechnology, Suzhou, China) according to the manufacturer's instructions. Bands were recorded by a digital camera (Canon, EOS 350D, Tokyo, Japan).

\subsection{Statistical Analyses}

Data are presented as means \pm SEM. Differences were evaluated using unpaired Student's t-tests. The level of statistical significance was set at $p<0.05$.

\section{Abbreviation}

HO-1: heme oxygenase-1; PKC: protein kinase C; $\mathrm{H}_{2} \mathrm{O}_{2}$ : hydrogen peroxide; ROS: reactive oxygen species.

\section{Acknowledgements}

The authors gratefully acknowledge the financial supports by the topic of Heilongjiang Provincial Education Bureau (Jing.Gu), the Research projects of Heilongjiang Provincial Health Bureau (2013-649).

\section{Conflict of Interest}

The authors declare no conflict of interest.

\section{References}

1. Keum YS, Owuor ED, Kim BR, Hu R, Kong AN. Involvement of Nrf2 and JNK1 in the activation of antioxidant responsive element (ARE) by chemopreventive agent phenethyl isothiocyanate (PEITC). Pharm Res. 2003; 20: 1351-1356.

2. Kong AN, Owuor E, Yu R. Induction of xenobiotic enzymes by the MAP kinase pathway and the antioxidant or electrophile response element (ARE/EpRE). Drug Metab Rev. 2001; 33: 255-271.

3. Hu R, Hebbar V, Kim BR. In vivo pharmacokinetics and regulation of gene expression profiles by isothiocyanate sulforaphane in the rat. J Pharmacol Exp Ther. 2004; 310: 263-271.

4. Ahmed K, Gerber DA, Cochet C. Joining the cell survival squad: an emerging role for protein kinase CK2. Trends Cell Biol. 2002; 12: 226-230.

5. Alia M, Ramos S, Mateos R, Bravo L, Goya L. Response of the antioxidant defense system to tert-butyl hydroperoxide and hydrogen peroxide in a human hepatoma cell line (HepG2). J. Biochem Mol Toxicol. 2005; 19: 119-128.

6. Riveiro ME, De Kimpe N, Moglioni A, Vazquez R, Monczor F, Shayo C, Davio C. Coumarins: old compounds with novel promising therapeutic perspectives. Curr Med Chem. 2010; 17: 1325-1328.

7. Satoh T, Enokido Y, Aoshima H, Uchiyama Y, Hatanaka H. Changes in mitochondrial membrane potential during oxidative stressinduced apoptosis in PC12 cells. J Neurosci Res. 1997; 50: 413-420.

8. Bourbon NA, Sandirasegarane L, Kester M. Ceramide-induced inhibition of Akt mediated through protein kinase C. J Biol Chem. 2002; 277: 3286-3292.
9. Uberti D, Piccioni L, Colzi A, Bravi D, Canonico PL, Memo M. Pergolide protects SH-SY5Y cells against neurodegeneration induced by $\mathrm{H}_{2} \mathrm{O}_{2}$. Eur J Pharmacol. 2002; 434: 17-20.

10. Chan PH. Reactive oxygen radicals in signaling and damage in the ischemic brain. J Cereb Blood Flow Metab. 2001; 21: 2-14.

11. Doornbos RP, Theelen M, Van der Hoeven PC, Van Blitterswijk WJ, Verkleij AJ, van Bergen en Henegouwen PMP. Protein kinase $\mathrm{C}$ is a negative regulator of protein kinase B activity. J Biol Chem. 1999; 2274: 8589-8596.

12. Ha JH, Noh HS; Shin IW, Hahm JR, Kim DR. Mitigation of $\mathrm{H}_{2} \mathrm{O}_{2}$-induced autophagic cell death by propofol in H9c2 cardiomyocytes. Cell biology and toxicology. 2012; 28 (1): 19-29.

13. Bennett BL, Sasaki DT, Murray BW, O'Leary EC, Sakata ST, Xu W, Leisten JC, Motiwala A, Pierce S., Satoh Y, Bhagwat SS, Manning AM, Anderson DW. SP 600125, an anthrapyrazolone inhibitor of Jun N-terminal kinase. Proc Natl Acad Sci. 2001; 98: 13681-13686.

14. Ushio-Fukai M, Alexander RW, Akers M, Yin Q, Fujio $Y$, Walsh K, Griendling KK. Reactive oxygen species mediate the activation of Akt/protein kinase B by angiotensin II in vascular smooth muscle cells. J Biol Chem. 1999; 274: 22699-22704.

15. Strasser A, O'Connor L, Dixit VM. Apoptosis signalling. Annu Rev Biochem. 2000; 69: 217-245.

16. Casamayor A, Morrice NA, Alessi DR. Phosphorylation of Ser-241 is essential for the activity of 3-phosphoinositide-dependent protein kinase-1: identification of five sites of phosphorylation in vivo. Biochem J. 1999; 342: 287-292.

17. Encinas M, Iglesias M, Llecha N, Comella JX. Extracellular regulated kinase and phosphatidylinositol 3-kinase are involved in brain-derived neurotrophic factor-mediated survival and neutritogenesis of the neuroblastoma cell line SH-SY5Y. J Neurochem. 1999; 73: 1409-1421.

18. Eckenhoff RG, Johansson JS, Wei H, Carnini A, Kang B, Wei W, Pidikiti R, Keller JM, Eckenhoff MF. Inhaled anesthetic enhancement of amyloid-beta oligomerization and cytotoxicity. Anesthesiology. 2004; 101: 703-709.

19. Crossthwaite AJ, Hasan S, Williams RJ. Hydrogen peroxide-mediated phosphorylation of ERK1/2, Akt/PKB and JNK in cortical neurones: dependence on $\mathrm{Ca}^{2+}$ and PI3-kinase. J Neurochem. 2002; 80: 24-35.

20. Dou F, Netzer WJ, Tanemura K, Li F, Hartl FU, Takashima A, Gouras GK, Greengard P, Xu H. Chaperones increase association of tau protein with microtubules. Proc Natl Acad Sci. USA 2003; 100: 721-726.

21. Paya M, Halliwell B, Hoult JR. Interactions of a series of coumarins with reactive oxygen species. Scavenging of superoxide, hypochlorous acid and hydroxyl radicals. Biochem Pharmacol. 1992; 44: 205-214.

22. Wang X, Zhang X, Cheng Y, Li C, Zhang W, Liu L, Ding Z. Alpha-lipoic acid prevents bupivacaine-induced neuron injury in vitro through a PI3K/Akt-dependent mechanism. Neurotoxicology. 2010; 31(1): 101-112.

23. Acquaviva R, Campisi A, Murabito P, Raciti G, Avola R, Mangiameli S, Musumeci I, Barcellona ML, Vanella A, Li VG. Propofol attenuates peroxynitrite-mediated DNA damage and apoptosis in cultured astrocytes: an alternative protective mechanism. Anesthesiology. 2004; 101: 1363-1371.

24. Son Y, Cheong YK, Kim NH, Chung HT, Kang DG, Pae HO. Mitogen-Activated Protein Kinases and Reactive Oxygen Species: How Can ROS Activate MAPK Pathways? Journal of Signal Transduction. 2011; doi:10.1155/2011/792639.

25. Cowan KJ, Storey KB. Mitogen-activated protein kinases: new signaling pathways functioning in cellular responses to environmental stress. The Journal of Experimental Biology. 2003; 206: 1107-1115.

26. Chang AYW. Pro-life role for c-Jun N-terminal kinase and p38 mitogen-activated protein kinase at rostral ventrolateral medulla in experimental brain stem death. Chang Journal of Biomedical Science. 2012; 19: $1-12$.

27. Wu XJ, Zheng YJ, Cui YY, Zhu L, Lu Y, Chen HZ. Propofol attenuates oxidative stress-induced PC12 cell injury via p38 MAP kinase dependent pathway. Acta pharmacologica Sinica. 2007; 28(8):1123-1128.

28. Cakatay U. Pro-oxidant actions of alpha-lipoic acid and dihydrolipoic acid. Med Hypotheses. 2006; 66(1): 110-117.

29. Tamagno E, Robino G, Obbili A, Bardin P, Aragno M, Parola M, Danni O. $\mathrm{H}_{2} \mathrm{O}_{2}$ and 4-hydroxynonenal mediate amyloid beta-induced neuronal apoptosis by activating JNKs and p38 MAPK. Exp Neurol. 2003; 180: 144-155.

30. Uberti D, Rizzini C, Spano PF, Memo M. Characterization of tau proteins in human neuroblastoma SH-SY5Y cell line. Neurosci Lett. 1997; 235: 149-153.

31. Brunet A, Datta SR, Greenberg ME. Transcription-dependent and independent control of neuronal survival by the PI3K-Akt signaling pathway. Curr Opin Neurobiol. 2001; 11: 297-305. 
32. Magrané J, Smith RC, Walsh K, Querfurth HW. Heat shock protein 70 participates in the neuroprotective response to intracellularly expressed beta-amyloid in neurons. J Neurosci. 2004; 24: 1700-1706.

33. Do SH, Ham BM, Zuo Z. Effects of propofol on the activity of rat glutamate transporter type 3 expressed in Xenopus oocytes: the role of protein kinase C. Neurosci Lett. 2003; 343: 113-116.

34. Chikutei K, Oyama TM, Ishida S, Okano Y, Kobayashi M, Matsui H, Horimoto K, Nishimura Y, Ueno SY, Oyama Y. Propofol, an anesthetic possessing neuroprotective action against oxidative stress, promotes the process of cell death induced by $\mathrm{H}_{2} \mathrm{O}_{2}$ in rat thymocytes. European journal of pharmacology. 2006; 540(1-3):18-23.

35. Dudek H, Datta SR, Franke TF, Birnbaum MJ, Ryoji Y, Cooper GM, Segal RA, kaplan DR, Greenberg ME. Regulation of neuronal survival by the serine-threonine protein kinase Akt. Science. 1997; 275: 661-665.

36. Ishii T, Yanagawa T, Tetsuya K, Yuki K, Seita J, Yoshida H, Bannai S. Murine peritoneal macrophages induce a novel $60-\mathrm{kDa}$ protein with structural similarity of a tyrosine kinase p56 lck -associated protein to oxidative stress. Biochem Biophys Res Commun. 1996; 226: 456-460.

37. Maines $M$. The heme oxygenase system: a regulator of second messenger gases. Ann Rev Pharmacol Toxicol. 1997; 37:517-554.

38. Earnshaw WC, Martins LM, Kaufmann SH. Mammalian caspases: structure, activation, substrates and functions during apoptosis. Annu Rev Biochem. 1999; 68:383-424.

39. Wang HX, Zhang G, Wang Q, Feng XS, Zong H. Propofol protects hepatic L02 cells from hydrogen peroxide-induced apoptosis via activation of extracellular signal-regulated kinases pathway. Anesthesia and analgesia. 2008; 107(2):534-40.

40. $\mathrm{Xu}$ JJJ, Wang YLL. Propofol attenuation of hydrogen peroxide-mediated oxidative stress and apoptosis in cultured cardiomyocytes involves haeme oxygenase-1. European journal of anaesthesiology. 2008; 25(5):395-402.

41. Liang C, Xue ZHG, Wang H, Li P. Propofol Upregulates Heme Oxygenase-1 Through Activation of ERKs in Human Umbilical Vein Endothelial Cells Under Oxidative Stress Conditions. Laboratory Investigation. 2011;23(3) :229-235 